\title{
Diesel Degradation in Soil by Fenton Process
}

\author{
Ricardo D. Villa, ${ }^{\#}$ Alam G. Trovó ${ }^{\S}$ and Raquel F. Pupo Nogueira* \\ Instituto de Química de Araraquara, UNESP - Universidade Estadual Paulista, CP 355, \\ 14801-970 Araraquara-SP, Brazil
}

\begin{abstract}
Este trabalho descreve a utilização do processo Fenton para degradação de diesel em solo e destaca aspectos comuns em situações reais de contaminação que podem afetar a eficiência da remediação. Foi observado que a maior parte dos hidrocarbonetos presentes no diesel com menos de 14 carbonos foi perdida por volatilização antes da remediação. Em solo franco, cerca de $80 \%$ do diesel foi degradado enquanto que em solo franco-argiloso a degradação foi inferior a $20 \%$. Adições múltiplas de $\mathrm{H}_{2} \mathrm{O}_{2}$ proporcionaram degradação de até $80 \%$ do diesel, enquanto que com adição única a degradação foi inferior a 14\%. A adição de ferro solúvel foi essencial para obtenção de altas porcentagens de degradação. Não foi observado aumento significativo ( $t$-test; $\mathrm{P}=0.05$ ) na degradação do diesel quando foram utilizadas dosagens de $\mathrm{H}_{2} \mathrm{O}_{2}$ entre 0,09 e $0,36 \mathrm{~g} \mathrm{~g}^{-1}$. Além disso, a alta dosagem de $\mathrm{H}_{2} \mathrm{O}_{2}\left(0,36 \mathrm{~g} \mathrm{~g}^{-1}\right)$ degradou $87 \%$ da matéria orgânica originalmente presente no solo.
\end{abstract}

This work reports the use of Fenton process for diesel degradation and addresses common aspects of real situations that can affect the soil remediation efficiency. It was observed that most of diesel hydrocarbons containing less than 14 carbon atoms were lost by volatilization prior to the treatment. About $80 \%$ degradation was achieved in a loam soil, while less than $20 \%$ was observed in a clay loam soil. The multiple additions of $\mathrm{H}_{2} \mathrm{O}_{2}$ resulted in $80 \%$ diesel degradation, while only $14 \%$ of diesel was degraded after a reaction time of $80 \mathrm{~h}$ using a single addition. The addition of soluble iron was essential to achieve high degradation levels. No significant increase in diesel degradation ( $t$-test; $\mathrm{P}=0.05$ ) was observed using $\mathrm{H}_{2} \mathrm{O}_{2}$ dosages between 0.09 and $0.36 \mathrm{~g} \mathrm{~g}^{-1}$. Furthermore, the highest $\mathrm{H}_{2} \mathrm{O}_{2}$ dosage applied $\left(0.36 \mathrm{~g} \mathrm{~g}^{-1}\right)$ degraded around $87 \%$ of the organic matter originally present in the soil.

Keywords: remediation, soil texture, fuel, hydrogen peroxide, short-chain alkanes

\section{Introduction}

Globally, about 3.5 trillion liters of crude oil are refined annually, and consumed as fuels, greases and lubricating oils. ${ }^{1}$ The extraction, handling, transportation and storage of such a volume of material often result in spills, which can cause water and soil contamination. ${ }^{2,3}$ In Brazil, one of the most serious reported environmental accidents involving oil derivatives occurred in Guanabara Bay in January 2000, when approximately 1.3 million liters of crude oil were spilled. The São Paulo State environmental protection

\footnotetext{
*e-mail: nogueira@iq.unesp.br

\#Present address: Departamento de Química, Universidade Federal de Mato Grosso, 78060-900 Cuiabá-MT, Brasil

${ }^{\S}$ Present address: Departamento de Biologia, Universidade Federal de Santa Maria, CP 511, 98300-000 Palmeira das Missões-RS, Brasil
}

agency (CETESB) reports that $78 \%$ of soil contamination in the State is caused by fuel spills from roadside filling stations. $^{4}$

Increasing soil contamination by fuels has motivated the development of various remediation techniques, among which are the in situ and ex situ chemical oxidation processes (ISCO and ESCO, respectively). ${ }^{5}$ These processes are commonly employed for the remediation of soils and groundwater contaminated with chemicals such as organochlorines and volatile organic compounds. ${ }^{6} \mathrm{ESCO}$ systems can be attractive for soil remediation when the contaminated site requires immediate treatment, as with fuel spills due to traffic accidents or in gas stations, where there are acute risks. In addition, ex situ systems permit good dispersion of reagents throughout the soil, and better control of the fate of contaminants and degradation products by recovery of the leachate. ${ }^{7}$ 
Several oxidative processes are based on oxidations mediated by hydroxyl radicals $\left({ }^{\circ} \mathrm{OH}\right)$, which have a high reduction potential $(2.73 \mathrm{~V}$ versus Normal Hydrogen Electrode) and are able to oxidize a wide variety of organic contaminants. ${ }^{8}$

One simple way of generating ${ }^{\circ} \mathrm{OH}$ is through the decomposition of hydrogen peroxide catalyzed by $\mathrm{Fe}^{2+}$ in acidic medium, known as the Fenton reaction. Many studies have highlighted the efficiency of Fenton processes for ex situ remediation of soils contaminated with pesticides, diesel, kerosene and other organic contaminants..$^{9-13}$ However, degradation processes have often been explored using simple systems, such as silica, as a model of soil, or with very low amounts of soil, generally in the range of 1.0 to $30 \mathrm{~g}$. These conditions do not allow evaluation of several parameters that could influence the effectiveness of the remediation process in the real environment, including contaminant volatilization, OM degradation, temperature variation, and soil characteristics.

The aim of the present work is to study the use of the Fenton process for the ex situ degradation of diesel in a soil slurry, and to address some of the aspects, common to real situations, that can affect degradation, such as the volatilization of diesel prior to application of the Fenton process, soil texture and OM content, the contribution of the mineral iron naturally present in soil, and dosage and mode of addition of $\mathrm{H}_{2} \mathrm{O}_{2}$.

\section{Experimental}

Reagents

The diesel used in the experiments was a commercial product obtained from a road fuel filling station. Pesticidegrade $n$-hexane solvent (Tedia) was used to prepare the diesel standard solutions and for diesel extraction from the soil. $\mathrm{H}_{2} \mathrm{O}_{2}(29 \%, \mathrm{~m} / \mathrm{v})$ from Synth was used in the degradation experiments, and $\mathrm{Na}_{2} \mathrm{SO}_{4}$ (Baker) was used as desiccant. The $\mathrm{Fe}^{2+}$ solutions were prepared by dissolving $\mathrm{FeSO}_{4} \cdot 7 \mathrm{H}_{2} \mathrm{O}$ (Carlo Erba) in $0.1 \mathrm{~mol} \mathrm{~L}^{-1} \mathrm{H}_{2} \mathrm{SO}_{4}$ (Synth). Solutions of $\mathrm{H}_{2} \mathrm{SO}_{4}$ (Synth) and/or $\mathrm{NaOH}$ (Synth) were used for $\mathrm{pH}$ adjustment. Ammonium metavanadate (Vetec) was used for the $\mathrm{H}_{2} \mathrm{O}_{2}$ determination. All the glassware was cleaned with Extran MA-01 detergent (10\%, v/v) from Merck.

\section{Evaluation of diesel volatilization}

For identification of diesel compounds volatilized from soil, $10 \mathrm{~g}$ of diesel-contaminated soil $\left(1.0 \mathrm{mg} \mathrm{g}^{-1}\right)$ were left in the open air for $24 \mathrm{~h}$. After this time, the diesel contained in the sample was extracted (described below) and the extracts analyzed using a gas chromatograph coupled to a mass spectrometer detector (GC-MS). The identification of diesel compounds remaining in the soil was achieved by comparison of the fragmentation profile of the diesel components with those provided in the instrument database (Shimadzu LabSolutions software). The chromatogram obtained for this extract was compared with that obtained for diesel maintained in a closed system, hence enabling identification of compounds that had been volatilized. Diesel compounds remaining in soil after application of the remediation process were identified in a similar way. All mass spectra had at least 90\% agreement with the fragmentation standards obtained from the equipment database. The percentage of diesel volatilized from soil was determined by mass difference, using an analytical balance with a precision of $\pm 0.1 \mathrm{mg}$ (Mettler Toledo AB204-S).

Since the variation of diesel mass caused by volatilization can introduce errors in quantification, the most volatile compounds were first eliminated. To this end, a volume of $200 \mathrm{~mL}$ of diesel was stirred for $12 \mathrm{~h}$, in the open air, in a $5 \mathrm{~cm}$ high beaker having an exposed surface area of $200 \mathrm{~cm}^{2}$. After this time, chromatographic analyses confirmed the loss of the most volatile compounds, as in the previous experiments using contaminated soil. Subsequent recovery tests and all degradation experiments, were performed using samples of diesel from which the most volatile compounds had been removed.

\section{Sampling and contamination of the soil}

Degradation of diesel was studied using two types of soil. Both were collected at the same location, in the central-west region of Brazil, however at different depths. One was collected at the surface $(0-4 \mathrm{~cm})$, and the other at 90-100 cm. After sampling, the soil was passed through a $3.0 \mathrm{~mm}$ sieve and dried in the open air at $25-30^{\circ} \mathrm{C}$ for $48 \mathrm{~h}$. The spiked soil was prepared by adding $200 \mathrm{~mL}$ of a diesel solution ( $50 \mathrm{~g} \mathrm{~L}^{-1}$ in $n$-hexane) to $2.0 \mathrm{~kg}$ of soil. Before the degradation experiments, the spiked soil was vigorously homogenized for $30 \mathrm{~min}$, then left standing for $24 \mathrm{~h}$ to completely eliminate hexane (confirmed by weight loss).

\section{Experimental conditions for degradation}

A slurry of diesel-spiked soil was prepared by directly mixing $500 \mathrm{~mL}$ of aqueous $12 \mathrm{mmol} \mathrm{L}^{-1} \mathrm{FeSO}_{4}$ solution and $150 \mathrm{~g}$ of contaminated soil $\left(5.0 \mathrm{mg} \mathrm{g}^{-1}\right)$. To evaluate the effects of hydrogen peroxide dosage added to the soil slurry, a total volume of $160 \mathrm{~mL}$ of solutions of $1.25,2.5$, 
5.0 or $10 \mathrm{~mol} \mathrm{~L}^{-1} \mathrm{H}_{2} \mathrm{O}_{2}$ was pumped into the slurry, in separate experiments, corresponding to the addition of a total dosage of $0.045,0.09,0.18$ and $0.36 \mathrm{~g}$ of $\mathrm{H}_{2} \mathrm{O}_{2} \mathrm{~g}^{-1}$ of soil, respectively. The $\mathrm{H}_{2} \mathrm{O}_{2}$ was added using a peristaltic pump (Ismatec model 78017-10), programmed to deliver $1.1 \mathrm{~mL}$ of $\mathrm{H}_{2} \mathrm{O}_{2}$ solution every $20 \mathrm{~min}$ for $12 \mathrm{~h}$. After $12 \mathrm{~h}$ reaction time, addition of $\mathrm{H}_{2} \mathrm{O}_{2}$ was interrupted for a further $12 \mathrm{~h}$, to allow for the consumption of the $\mathrm{H}_{2} \mathrm{O}_{2}$, and then restarted. A total of 145 additions were made in each experiment employing step additions of $\mathrm{H}_{2} \mathrm{O}_{2}$. In the experiment using a single addition of hydrogen peroxide, a dose of $0.36 \mathrm{~g} \mathrm{H}_{2} \mathrm{O}_{2} \mathrm{~g}^{-1}$ was added to the slurry. The dose of $\mathrm{H}_{2} \mathrm{O}_{2}$ was $0.045 \mathrm{~g} \mathrm{~g}^{-1}$ in the experiment where the mineral iron contribution (in the absence of soluble iron) was evaluated. All experiments were carried out at an ambient temperature of $28^{\circ} \mathrm{C}$, under mechanical stirring (110 rpm). The $\mathrm{pH}$ of the slurries was adjusted to 2.5-3.0, the optimum $\mathrm{pH}$ for the Fenton reaction in soil, ${ }^{14}$ by the addition of $3 \mathrm{~mol} \mathrm{~L}^{-1} \mathrm{H}_{2} \mathrm{SO}_{4}$ solution before starting the experiments. No further $\mathrm{pH}$ adjustment was made during the experiments.

\section{Chemical analysis}

Extraction of diesel from the soil was carried out by adding $7.0 \mathrm{~mL}$ of $n$-hexane/dichloromethane solution (1:1) and $1.0 \mathrm{~g}$ of anhydrous sodium sulfate (to assist in moisture removal and dispersal of soil particles) to $3.0 \mathrm{~g}$ of spiked soil in an airtight sealed glass tube $(2 \mathrm{~cm}$ internal diameter and $15 \mathrm{~cm}$ long). The mixture was mechanically stirred at $240 \mathrm{rpm}$ for $2 \mathrm{~h}$, and then centrifuged and the extract collected. This extraction procedure was repeated two more times. The soil extracts were combined, and the diesel quantified by gas chromatography with flame ionization detection (GC-FID), using a Shimadzu 14B chromatograph equipped with a DB-5 capillary column $(0.32 \mathrm{~mm} \times 30 \mathrm{~m})$. The following chromatographic conditions were used: injector temperature, $280^{\circ} \mathrm{C}$; initial furnace temperature, $45^{\circ} \mathrm{C}$; final furnace temperature, $250{ }^{\circ} \mathrm{C}$; heating rate, $12{ }^{\circ} \mathrm{C} \min ^{-1}$; detector temperature, $330{ }^{\circ} \mathrm{C} ; \mathrm{H}_{2}$ as carrier gas at a flow rate of $10 \mathrm{~mL} \mathrm{~min}^{-1}$. The diesel concentration determination was based on the sum of the total peak area, according to EPA method 8015B. Individual compounds were identified using a gas chromatograph (Shimadzu 17A) coupled to a mass spectrometer (QP-5000), under similar chromatographic conditions as used for diesel quantitation. For the diesel concentrations evaluated $\left(0.2-10 \mathrm{~g} \mathrm{~kg}^{-1}\right)$, the extraction method recovery percentages ranged from 80 to $95 \%$, with relative standard deviations between 2.5 and $10 \%$. The residual $\mathrm{H}_{2} \mathrm{O}_{2}$ concentration was monitored using a spectrophotometric method employing ammonium metavanadate. ${ }^{15}$
The relative abundance of iron minerals was determined by X-ray fluorescence in a Shimadzu EDX-800 diffractometer. The $\mathrm{pH}$ was determined in water. ${ }^{16}$ The soil OM content was determined by thermogravimetric analysis (TG), using a Simultaneous Thermal Analysis Module (TA Instruments, model number SDT-2960).

\section{Results and Discussion}

\section{Diesel volatilization from soil}

Soil contaminated due to fuel spillage usually remains exposed to the air for periods of time that can vary from days to years, before application of any remediation process. This exposure favors the loss of volatile compounds, which will therefore not be targeted during the remediation. Comparing the chromatogram corresponding to the diesel that had remained in a closed system, with that for diesel extracted from the soil after exposure to the open air (Figure 1), it can be observed that the lightest fraction of the fuel was volatilized during exposure. This fraction contains $n$-alkanes with carbon chains possessing fewer than 14 carbon atoms, together with several other unsaturated and/or cyclic hydrocarbons whose peaks appear at retention times between 5 and $15 \mathrm{~min}$, and corresponds to $8 \%$ of the original diesel mass (as determined by gravimetric analysis).

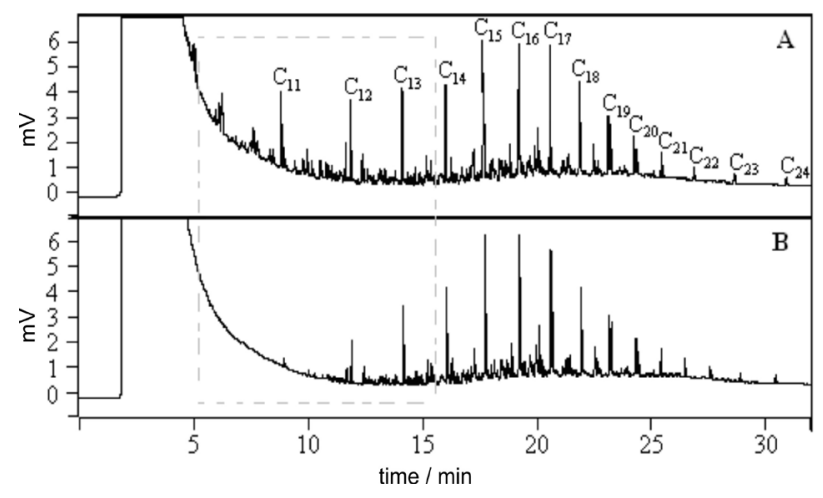

Figure 1. Chromatograms of (A) commercial diesel that had remained in a closed system, and (B) extract of the loam soil contaminated with diesel that had been exposed to the open air for $12 \mathrm{~h} . \mathrm{C}_{11}, \mathrm{C}_{12}, \mathrm{C}_{13} \ldots \mathrm{C}_{24}$ refer to $n$-alkanes with chain lengths of between 11 and 24 carbon atoms.

These results indicate that when diesel-contaminated soil remains exposed to the open air for at least $24 \mathrm{~h}$ at temperatures between $25{ }^{\circ} \mathrm{C}$ and $35{ }^{\circ} \mathrm{C}$, temperatures common in tropical countries, it will probably lose by volatilization those hydrocarbons with chain lengths less than 14 carbons. Furthermore, it is probable that aromatic hydrocarbons, such as benzene, toluene and xylene, are also volatilized since they have higher vapor pressures than 
Table 1. Characteristics of the soils used in the degradation experiments

\begin{tabular}{|c|c|c|c|c|c|c|}
\hline \multirow[t]{2}{*}{ Soil } & \multirow{2}{*}{$\begin{array}{c}\mathrm{pH} \\
\left(\mathrm{H}_{2} \mathrm{O}\right)\end{array}$} & $\mathrm{OM}$ & Sand & Silt & Clay & \multirow{2}{*}{$\begin{array}{c}\text { Textural* } \\
\text { classes }\end{array}$} \\
\hline & & \multicolumn{4}{|c|}{$\%$} & \\
\hline Surface $(0-4 \mathrm{~cm})$ & 5.7 & 7.5 & 41 & 47 & 12 & loam \\
\hline Depth $(90-100 \mathrm{~cm})$ & 6.7 & 0.5 & 30 & 36 & 33 & clay loam \\
\hline
\end{tabular}

*Classified according to the textural triangle described by Brady and Buckman. ${ }^{18}$

14 carbon $n$-alkanes. Although the volatilized fraction is small, as observed in the present work and elsewhere, ${ }^{3}$ it is significant, since it can contain a greater proportion of toxic compounds than the material remaining in the soil. For example, petroleum hydrocarbons containing up to ten carbon atoms are characterized by high acute toxicity. These compounds quickly evaporate and do not persist in soil. However, petroleum hydrocarbons with more than 20 carbon atoms, most of which are waxes and asphaltenes, do not show significant bioavailability or toxicity. ${ }^{17}$ Hence, the efficiency of a remediation process can be overestimated, due to volatilization, especially in ex situ treatments involving soil removal and transportation, where such losses are favored.

\section{Influence of soil texture on diesel degradation}

The soils collected at two different depths differed considerably in terms of texture, $\mathrm{pH}$ and $\mathrm{OM}$ content (Table 1). The surface soil was slightly acidic and would be classified as a loam soil. The soil collected at $90-100 \mathrm{~cm}$ depth would be classified as a clay loam; its $\mathrm{pH}$ was neutral and it was practically free of OM.

Soil texture can strongly influence remediation processes such as vapor extraction, thermal desorption and soil washing. ${ }^{19,20}$ In the present study, the efficiency of diesel degradation by the Fenton process was also found to be strongly influenced by soil texture. About 20\% degradation of diesel was observed for the clay loam soil, while approximately $80 \%$ degradation was achieved for the loam soil, under the same oxidizing conditions (Figure 2).

The large surface area of clay loam soil results in efficient contaminant adsorption, which reduces its exposure to hydroxyl radical attack. According to Watts et al.,${ }^{21}$ adsorbed contaminants are not easily attacked by hydroxyl radicals, due to mass transfer limitations. Furthermore, clay soils have low permeability, and high forces of cohesion between particles hinder the dispersion of oxidizing species.

The OM generally plays an important role in the sorption of organic contaminants in soil, and consequently in the degradation process. According to Spark and Swift, ${ }^{22}$ the sorption of organic compounds is complex and may

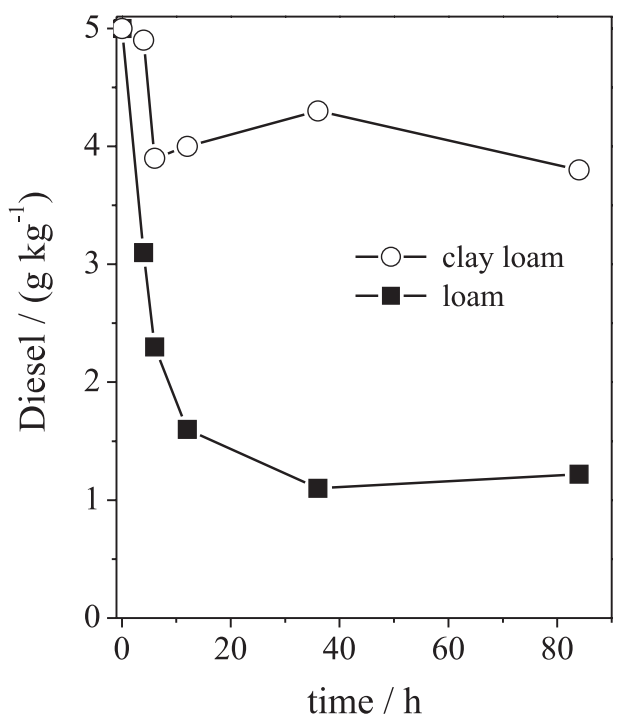

Figure 2. Comparison of diesel degradation in clay loam soil and loam soil. Experimental conditions: $\left[\mathrm{Fe}^{2+}\right]=12 \mathrm{mmol} \mathrm{L}^{-1} ; \mathrm{H}_{2} \mathrm{O}_{2}$ dosage: $0.09 \mathrm{~g} \mathrm{~g}^{-1}$ (145 additions of $93.54 \mathrm{mg}$ of $\mathrm{H}_{2} \mathrm{O}_{2}$ every $20 \mathrm{~min}$ ).

involve both the organic and inorganic fraction of the soil. They also state that the organic matter may govern the sorption of contaminants when corresponding to more than $5 \%$ of the soil. The results of the present study suggest that the soil texture played more important role than the organic matter in the sorption of diesel. In case of the soil collected at the surface, about $70 \%$ of the organic matter originally present in the soil was degraded together with the diesel and therefore did not contribute to the sorption process. In the case of the deep soil, the low organic matter content $(0.5 \%)$ probably played little influence on the sorption process. Another aspect regarding the organic matter from the soil is that it may consume $\mathrm{H}_{2} \mathrm{O}_{2}$ and $\mathrm{HO}^{\circ}$ contributing to the loss of the Fenton process efficiency for the degradation of the target compound. However, in the present study it was not possible to evaluate the consumption of hydrogen peroxide by $\mathrm{OM}$ since the studied soils presented very different texture.

Approximately $39 \%$ of Brazilian soils are latosoils, ${ }^{23}$ characterized according to the Brazilian System of Soil Classification as deep, homogeneous, and with a texture varying from moderately to very clayey. These characteristics can hinder application of the Fenton process for remediation of deep contamination in many regions of 
Brazil. Since the percentage of diesel degradation in clay loam soil was very low (20\%), all subsequent experiments were carried out using loam soil collected at the surface.

\section{Influence of mineral iron in diesel degradation}

Iron is the fourth most abundant element in the Earth's crust, occurring in various minerals mainly in the form of oxides. ${ }^{24}$ Several workers have suggested that these minerals may participate in the Fenton reaction, making further addition of soluble iron unnecessary. ${ }^{25,26}$ However, in the present work, it was observed that after $6 \mathrm{~h}$ reaction time, using sequential additions of $\mathrm{H}_{2} \mathrm{O}_{2}$ (total dosage $0.045 \mathrm{~g}$ of $\mathrm{H}_{2} \mathrm{O}_{2} \mathrm{~g}^{-1}$ of soil) without addition of soluble iron, only $28 \%$ of diesel was degraded. In the presence of $12 \mathrm{mmol} \mathrm{L}^{-1} \mathrm{Fe}^{2+}$, removal of diesel reached $48 \%$, for the same period of time and $\mathrm{H}_{2} \mathrm{O}_{2}$ dosage (Figure 3). This corresponds to an initial degradation rate of $0.23 \mathrm{~g} \mathrm{~kg}^{-1} \mathrm{~h}^{-1}$ in the presence of mineral iron, compared to $0.40 \mathrm{~g} \mathrm{~kg}^{-1} \mathrm{~h}^{-1}$ for soluble iron. $45 \%$ of diesel was degraded after $84 \mathrm{~h}$ reaction time in the presence of mineral iron alone, while the same result was achieved in less than $6 \mathrm{~h}$ with addition of soluble iron. The catalytic decomposition of $\mathrm{H}_{2} \mathrm{O}_{2}$ by mineral iron is generally slower than with soluble iron due to the lower availability of the metal ion in solution in the heterogeneous system. Furthermore, since decomposition only occurs on the mineral surface, it is dependent on variables such as surface area and mass transfer of reagents. ${ }^{27}$

In the experiments with addition of $\mathrm{Fe}^{2+}$, the initial rate of $\mathrm{H}_{2} \mathrm{O}_{2}$ decomposition was $0.32 \mathrm{mmol} \mathrm{min}^{-1}$, while in the presence of mineral iron alone it achieved only $0.1 \mathrm{mmol} \mathrm{min} \mathrm{m}^{-1}$ in the first $90 \mathrm{~min}$ of reaction. The low

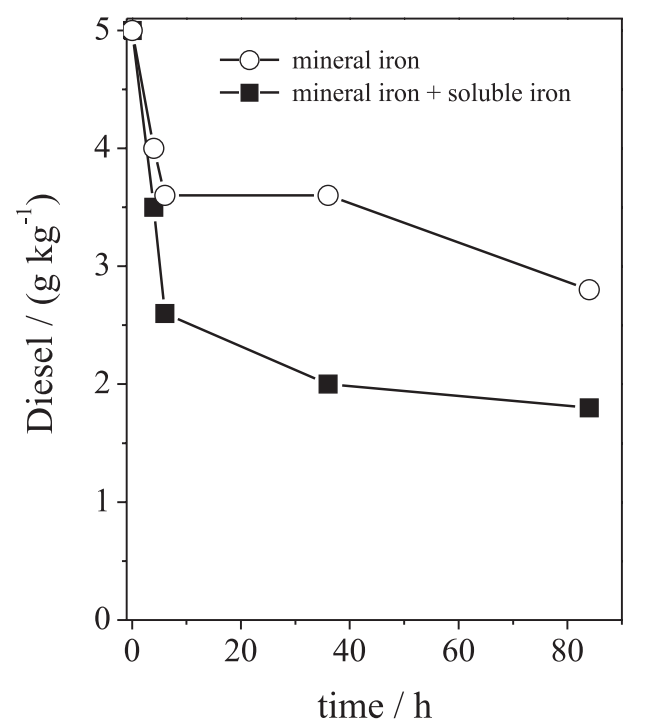

Figure 3. Diesel degradation in loam soil using mineral and soluble iron. Experimental conditions: $\left[\mathrm{Fe}^{2+}\right]=12 \mathrm{mmol} \mathrm{L}{ }^{-1} ; \mathrm{H}_{2} \mathrm{O}_{2}$ dosage: $0.045 \mathrm{~g} \mathrm{~g}^{-1}$ (145 additions of $46.75 \mathrm{mg}$ every $20 \mathrm{~min}$ ).
$\mathrm{H}_{2} \mathrm{O}_{2}$ consumption indicates the low catalytic activity of this mineral, and consequently the weak generation of ${ }^{\circ} \mathrm{OH}$ radicals and concomitant slow rate of diesel degradation.

Amongst the most abundant iron minerals in soils, hematite is least effective for $\mathrm{H}_{2} \mathrm{O}_{2}$ decomposition, ${ }^{14,27}$ because it is composed exclusively of $\mathrm{Fe}$ (III) species, which possess low catalytic activity. This could explain the poor degradation of diesel in the absence of soluble iron addition, since the soil used in the present study was rich in hematite. About $15 \%(\mathrm{~m} / \mathrm{m})$ of all oxides present in this soil are in the form of hematite, while the percentage of other iron oxides is lower than $0.4 \% .{ }^{28}$ All subsequent experiments were carried out with addition of soluble iron.

\section{Effect of dosage and mode of $\mathrm{H}_{2} \mathrm{O}_{2}$ addition}

Although a single addition of $\mathrm{H}_{2} \mathrm{O}_{2}$ simplifies the process, it was observed that step additions of $\mathrm{H}_{2} \mathrm{O}_{2}$ increased the efficiency of treatment. With a single addition to the slurry of a $0.36 \mathrm{~g} \mathrm{~g}^{-1}$ dose of hydrogen peroxide, only $14 \%$ diesel degradation was achieved in the first $2 \mathrm{~h}$ of reaction time, with no further degradation up to $84 \mathrm{~h}$. In comparison, $80 \%$ degradation was obtained using step additions of hydrogen peroxide, and the same total dosage (Figure 4).

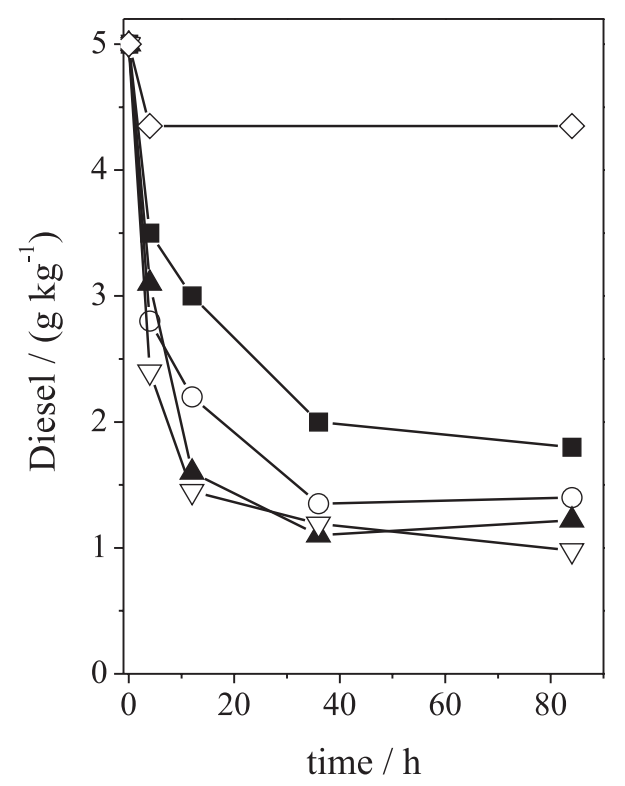

Figure 4. Influence of initial $\mathrm{H}_{2} \mathrm{O}_{2}$ concentration and mode of addition on the degradation of diesel in loam soil. $-\diamond-$ Single addition of $0.36 \mathrm{~g} \mathrm{~g}^{-1}$ of soil; - $-0.045 \mathrm{~g} \mathrm{~g}^{-1} ;-\bigcirc-0.09 \mathrm{~g} \mathrm{~g}^{-1} ;-\boldsymbol{\Lambda}-0.18 \mathrm{~g} \mathrm{~g}^{-1} ;-\nabla-0.36 \mathrm{~g} \mathrm{~g}^{-1}$ (145 additions of $47 \mathrm{mg}, 94 \mathrm{mg}, 188 \mathrm{mg}$ and $376 \mathrm{mg}$ of $\mathrm{H}_{2} \mathrm{O}_{2}$, respectively, every $20 \mathrm{~min}) ;\left[\mathrm{Fe}^{2+}\right]=12 \mathrm{mmol} \mathrm{L}^{-1}$.

A single addition results in a high concentration of $\mathrm{H}_{2} \mathrm{O}_{2}$ in the reaction medium, which favors self-decomposition reactions (equation 1) and scavenging of hydroxyl 
radicals by excess $\mathrm{H}_{2} \mathrm{O}_{2}$ (equation 2), hence decreasing the efficiency of the degradation processes. ${ }^{29}$

$\mathrm{H}_{2} \mathrm{O}_{2}+\mathrm{H}_{2} \mathrm{O}_{2} \rightarrow 2 \mathrm{H}_{2} \mathrm{O}+\mathrm{O}_{2}$

$\mathrm{H}_{2} \mathrm{O}_{2}+\mathrm{HO}^{\cdot} \rightarrow \mathrm{H}_{2} \mathrm{O}+\mathrm{HO}_{2}^{*}$

In the single addition experiment, the $\mathrm{H}_{2} \mathrm{O}_{2}$ was totally consumed in $20 \mathrm{~min}$, which explains the absence of further degradation after $2 \mathrm{~h}$ reaction time. Furthermore, the single addition caused an abrupt temperature increase, from 28 to $72{ }^{\circ} \mathrm{C}$ in $17 \mathrm{~min}$, which contributes to the decomposition of $\mathrm{H}_{2} \mathrm{O}_{2}$ to $\mathrm{H}_{2} \mathrm{O}$ and $\mathrm{O}_{2}$, and probably to the loss of volatile compounds during the degradation process. ${ }^{30}$ No significant increase in temperature was observed during experiments employing step additions.

The total costs and efficiencies of remediation processes using Fenton reactions are highly dependent on the amount of $\mathrm{H}_{2} \mathrm{O}_{2}$ used. . $^{9,253}$ The results obtained here showed that although an increased $\mathrm{H}_{2} \mathrm{O}_{2}$ dosage, from $0.045 \mathrm{~g} \mathrm{~g}^{-1}$ to $0.18 \mathrm{~g} \mathrm{~g}^{-1}$ of soil, improved the initial rate of degradation in the first $12 \mathrm{~h}$ of reaction time, no significant difference $(t$-test at $95 \%)$ in the degradation percentages (between 72 and $80 \%$ ) was observed after $36 \mathrm{~h}$ reaction time for $\mathrm{H}_{2} \mathrm{O}_{2}$ dosages of between $0.09 \mathrm{~g} \mathrm{~g}^{-1}$ and $0.36 \mathrm{~g} \mathrm{~g}^{-1}$.

Watts and Dilly ${ }^{9}$ reported that the use of high concentrations of $\mathrm{H}_{2} \mathrm{O}_{2}$ for soil remediation resulted in a fast decrease of soluble iron concentration after thirty minutes of reaction time due to the formation of amorphous iron flakes, which were insoluble in water and hindered the degradation reactions. In agreement with those observations, in the present study it was found that the rate of $\mathrm{H}_{2} \mathrm{O}_{2}$ consumption decreased gradually with time, especially in experiments where greater amounts of $\mathrm{H}_{2} \mathrm{O}_{2}$ were added. No consumption of $\mathrm{H}_{2} \mathrm{O}_{2}$ was observed after $76 \mathrm{~h}$ in the experiment with $0.36 \mathrm{~g} \mathrm{~g}^{-1} \mathrm{H}_{2} \mathrm{O}_{2}$ dosage, while in the experiments with dosages of $0.09 \mathrm{~g} \mathrm{~g}^{-1}$ and $0.18 \mathrm{~g} \mathrm{~g}^{-1}$, consumptions of about $3.4 \mu \mathrm{g} \mathrm{min}^{-1}$ and $6.5 \mu \mathrm{g} \mathrm{min}^{-1}$ of $\mathrm{H}_{2} \mathrm{O}_{2}$ were observed, respectively. Total consumption occurred after $15 \mathrm{~min}$ in the experiment with $0.045 \mathrm{~g} \mathrm{~g}^{-1}$ $\mathrm{H}_{2} \mathrm{O}_{2}$. In addition to formation of insoluble iron species, the scavenging of hydroxyl radicals by $\mathrm{H}_{2} \mathrm{O}_{2}$ can also decrease the efficiency of degradation in a medium containing excess hydrogen peroxide, as mentioned previously (equation 2).

After $40 \mathrm{~h}$ reaction time, practically no further diesel degradation occurred in any of the experiments. GC-MS analysis showed that the fraction of diesel remaining in the soil after this time contained mainly saturated aliphatic hydrocarbons with carbon chain lengths greater than 17 carbons (Figure 5b). Hydrocarbons with longer chains are more hydrophobic, and consequently tend to remain adsorbed to soil, where they are less susceptible to degradation processes. ${ }^{21}$ Comparing the chromatograms presented in Figure 5, it can be observed that the diesel components with less than 17 carbon atoms in the chain are totally degraded, while those with longer chain lengths are more persistent in the soil.

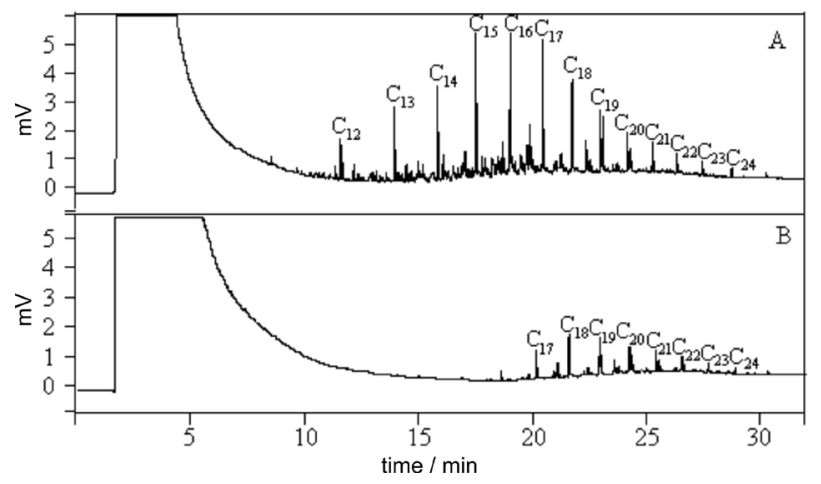

Figure 5. Chromatogram of soil extracts, (A) before and (B) after $84 \mathrm{~h}$ of reaction time. Experimental conditions: $\left[\mathrm{Fe}^{2+}\right]=12 \mathrm{mmol} \mathrm{L}^{-1} ; \mathrm{H}_{2} \mathrm{O}_{2}$ dosage: $0.36 \mathrm{~g} \mathrm{~g}^{-1}$ (145 additions of $376 \mathrm{mg}$ ).

The amount of OM remaining in the soil after the Fenton treatment was also influenced by the $\mathrm{H}_{2} \mathrm{O}_{2}$ dosage used. The greater the amount of $\mathrm{H}_{2} \mathrm{O}_{2}$ added during treatment, the larger was the amount of organic matter degraded (Figure 6). These results indicate that the process is extremely aggressive to the soil. The use of $0.36 \mathrm{~g} \mathrm{~g}^{-1}$ $\mathrm{H}_{2} \mathrm{O}_{2}$, for example, resulted in $87 \%$ degradation of the $\mathrm{OM}$ originally present in the soil. Besides contributing to soil degradation, the Fenton process also causes soil sterilization. Ferguson et al. ${ }^{30}$ observed the elimination of a large part of the native microorganisms present in soil,

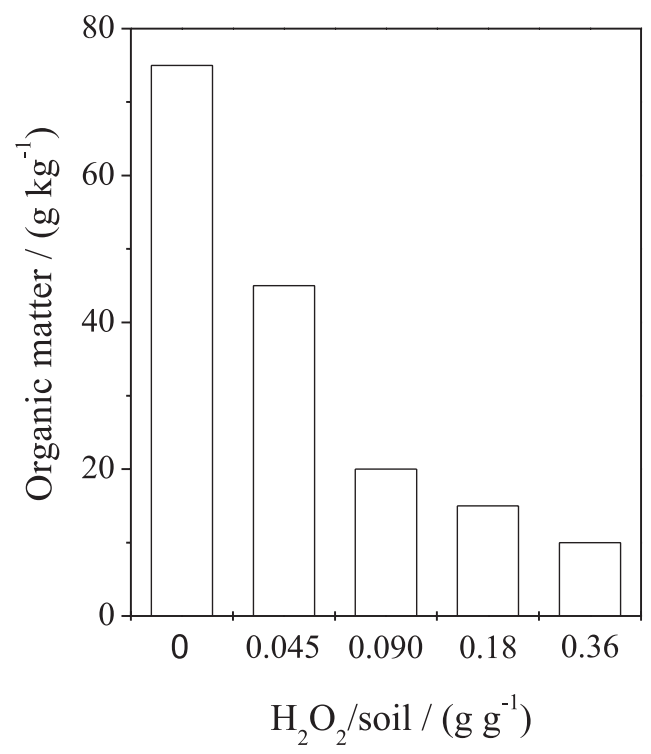

Figure 6. Organic matter concentration in the loam soil after addition of different $\mathrm{H}_{2} \mathrm{O}_{2}$ amounts. $\left[\mathrm{Fe}^{2+}\right]=12 \mathrm{mmol} \mathrm{L}{ }^{-1}$. 
following application of the Fenton process for remediation of diesel-contaminated soil. They attributed the death of microorganisms to the strong oxidizing conditions of the medium, $\mathrm{pH}$ change, and increase of the soil temperature during application of hydrogen peroxide. Metal dissolution and volatilization of contaminants may also occur during the Fenton treatment, which can make the remediation processes unfeasible. ${ }^{32}$

\section{Conclusions}

Considering the data reported in this work, it can be concluded that $(i)$ at temperatures between 25 and $35^{\circ} \mathrm{C}$, common in tropical countries, the light fraction of diesel will probably not be the target of any remediation process, since it is volatilized from soil within a few hours following contamination; (ii) the granular structure of contaminated soil has a large influence on the efficiency of diesel degradation by Fenton processes; the Fenton process can be highly efficient for surface soil remediation, but completely inadequate in the case of deeper soils with higher clay contents; (iii) the use of soluble iron increases the degradation rate in comparison to mineral iron such as hematite and may be necessary, even for soils rich in iron minerals such as hematite; (iv) $\mathrm{H}_{2} \mathrm{O}_{2}$ must be added in steps, in order to achieve greater efficiency and minimize the loss of volatile contaminants due to temperature increases; $(v)$ the results suggest that it can be advantageous to add $\mathrm{H}_{2} \mathrm{O}_{2}$ in dosages of between 0.09 and $0.18 \mathrm{~g} \mathrm{~g}^{-1}$, and to interrupt $\mathrm{H}_{2} \mathrm{O}_{2}$ addition after $12 \mathrm{~h}$, since highest degradation rates were obtained in the first $12 \mathrm{~h}$ of reaction time, after which degradation was slow in all cases, even using step additions of $\mathrm{H}_{2} \mathrm{O}_{2}$. Adoption of these procedures can contribute to soil preservation, and reduce costs and treatment time, so that the Fenton process can be used as an alternative to other methods of soil remediation, such as biodegradation. (vi) It is important to highlight that in this study the degradation was evaluated in an ex-situ system and that in an in situ remediation, other factors must be considered including the amount of macro and microporous of soil, what influences the sorption of diesel and the dispersion of reagents in soil and consequently the degradation efficiency.

\section{Acknowledgments}

The authors thank CAPES and FAPESP (05/00172-0) for scholarships to R. D. Villa and A. G. Trovó, respectively. The authors also thank Dr. M. R. de Marchi for use of the GC-FID, and Dr. M. S. Crespi for TG analysis.

\section{References}

1. Xie, G.; Barcelona, M. J.; Environ. Sci. Technol. 2003, 37, 4751.

2. Edgara, G. J.; Barrett, N. S.; Mar. Pollut. Bull. 2000, 40, 36.

3. Namkoong, W.; Hwang, E-Y.; Park, J-S.; Choi, J-H.; Environ. Pollut. 2002, 119, 23.

4. http://www.cetesb.sp.gov.br/Solo/areas_contaminadas/relacao_ areas.asp, accessed in March 2009.

5. http://www.frtr.gov/matrix2/section3/3_5.html, accessed in March 2009.

6. http://www.clu-in.org/download/remed/chemox.pdf, accessed in March 2009.

7. Hyman, M.; Dupont, R. R.; Groundwater and Soil Remediation: Process Design and Cost Estimating of Proven Technologies, ASCE Press: Reston, VA, 2001.

8. Pignatello, J. J.; Oliveros, E.; Mackay, A.; Crit. Rev. Environ. Sci. Technol. 2006, 36, 1.

9. Watts, R. J.; Dilly, S. E.; J. Hazard. Mater. 1996, 51, 209.

10. Kong, S.; Watts, R. J.; Choi, J.; Chemosphere 1998, 37, 1473.

11. Millioli, V. S.; Freire, D. D. C.; Cammarota, M. C.; J. Hazard. Mater. 2003, 103, 79.

12. Cravato, G.; Di Carlo, S.; Ondruschka, B.; Tumiatti, V.; Roggero, C. M.; Chemosphere 2007, 69, 1326.

13. Jonsson, S.; Persson, Y.; Frannkki, S.; van Bavel, B.; Lundstedt, S.; Haglund, P.; Tysklind, M.; J. Hazard. Mater. 2007, 149, 86.

14. Watts, R. J.; Udell, M. D.; Rauch, P. A.; Hazard. Waste Hazard. Mat. 1990, 7, 335.

15. Nogueira,R. F. P.; Oliveira, M. C.; Paterlini, W. C.; Talanta 2005, 66, 86.

16. EMBRAPA - Empresa Brasileira de Pesquisa Agropecuária; Manual de Métodos de Análise de Solo, Rio de Janeiro, Brasil, 1997.

17. http://response.restoration.noaa.gov/book_shelf/678_Chapter2. pdf, accessed in March 2009.

18. Brady, N. C.; Buckman, H. O.; Natureza e Propriedades do Solo, Freitas Bastos: Rio de Janeiro, Brasil, 1983.

19. Hamby, D. M.; Sci. Total Environ. 1996, 191, 203.

20. Khan, F. I.; Husain, T.; Hejazi, R.; J. Environ. Manage. 2004, $71,95$.

21. Watts, R. J.; Kong, S.; Dippre, M.; Barnes, W.; J. Hazard. Mater. 1994, 39, 33 .

22. Spark, K. M.; Swift, R. S.; Sci. Total Environ. 2002, 298,147.

23. Nicolella, A. C.; Dragone, D. S.; Bacha, C. J. C.; Rev. Econ. Sociol. Rural 2005, 43, 81.

24. vanLoon, G. W.; Duffy, S. J.; Environmental Chemistry, Oxford University Press: New York, 2000.

25. Watts, R. J.; Bottemberg, B. C.; Hess, T. F.; Jensen, M. D.; Teel, A. L.; Environ. Sci. Technol. 1999, 33, 3432.

26. Teel, A. L.; Warberg, C. R.; Atkinson, D. A.; Watts, R. J.; Water Res. 2001, 35, 977. 
27. Huang, H-H.; Lu, M-C.; Chen, J-N.; Water Res. 2001, 35, 2291.

28. Villa, R. D.; Nogueira, R. F. P.; Sci. Total Environ. 2006, 371, 11.

29. Parra, S.; Sarria, V.; Malato, S.; Péringer, P.; Pulgarin, C.; Appl. Catal., B 2000, 27, 153.

30. Ferguson, S. H.; Woinarski, A. Z.; Snape, I.; Morris, C. E.; Revill, A. T.; Cold Regions Sci. Tech. 2004, 40, 47.
31. Goi, A.; Trapido, M.; Chemosphere 2002, 46, 913.

32. Villa, R. D.; Trovó, A. G.; Nogueira, R. F. P.; Chemosphere 2008, 71, 43 .

Received: August 25, 2009

Web Release Date: March 11, 2010

FAPESP helped in meeting the publication costs of this article. 